\title{
Synthesis and Application of Hematite from Lathe Waste as Anti-Swelling on Wood
}

\author{
Lilik Miftahul Khoiroh ${ }^{1 *}$ \\ ${ }^{\text {I}}$ Chemistry Department, Science and Technology Faculty, Universitas Islam Negeri Maulana Malik Ibrahim Malang, \\ Jl. Gajayana 50 Malang, 65144, Indonesia \\ ${ }^{*}$ Corresponding author. Email: lilikmfx@kim.uin-malang.ac.id
}

\begin{abstract}
Hematite is one of iron oxide, which potentially in reducing swelling wood. The cellulose content in wood easily binds with hydrogen that causing swelling. Hematite was synthesized from iron lathe waste via ferric precursor by a precipitation-calcination method. The product synthesized is characterized using X-Ray Diffraction (XRD), Scanning Electron Microscopy (SEM), Fourier Transform - Infrared Spectroscopy (FT-IR), color reader. The hematite pigmented wood powder analyzed swelling ratio to know the ability to reduce swelling. XRD data and FT-IR spectrum confirmed that after calcination obtained hematite. SEM image revealed the shape of hematite was spherical and uniform. Color reader data showed that product calcined got chroma, hue, lightness, degree of redness, and yellowness according to hematite standard. Swelling ratio analysis resulted that wood powder after interaction with hematite using $\mathrm{H}_{2} \mathrm{SO}_{4}$ solvent did not swell, and using methanol solvent was swelled power after 8 hours of $4.76 \%$.
\end{abstract}

Keywords: hematite, pigment, wood, anti-swelling

\section{INTRODUCTION}

Swelling in wood is a structural change caused by the relative humidity of the atmosphere [1]. Wood consists of cellulose around 38-51\%, glucomannan around 14-20 $\%$, lignin by $21-31 \%$, xylan around $14-30 \%$, and other polysaccharide around 2-4 \% [2], [3]. In the amorphous cellulose area, $\mathrm{OH}$ group arrangement is irregular to bind between hydrogen and water molecules [4]. According to Howsinon., J. A, the higher the degree of crystallinity of cellulose, the lower its water absorption. The degree crystallinity of wood pulp by $57 \%$ has to access to a formation with hydrate of $53 \%$. In comparison, cotton with a degree of crystallinity of $67 \%$ has the power of formation with a hydrate of $44 \%$ [5].

One of the solutions to overcome swelling on wood is pigmented [6]. According to Schirp, Plinke, and Napolow, the brown iron oxide pigment from Bayferrox applied to wood-plastic composites can reduce its swelling power by about $44 \%$ compared to other dyes [7]. Crystallinity degree of cellulose increase with hematite pigment to suppress bonds with hydrates.

Iron oxide as a pigment because it has a variety of colors with different structures. Yellow is goethite; black is magnetite; brown is maghemite; red is hematite; and many others. Besides, iron oxide pigments are weather- resistant, relatively inert, and nontoxic. Hematite iron oxide is also the most stable iron oxide phase among the others. Hematite is a red iron oxide pigment with the structural formula $\left(\alpha-\mathrm{Fe}_{2} \mathrm{O}_{3}\right)$. Cornell and Schwertmann [8] explained that iron oxides could be synthesized from iron, $\mathrm{Fe}^{2+}$, or $\mathrm{Fe}^{3+}$. Hematite can be synthesized from pure compounds or iron lathe waste. Khoiroh, in his research, explained that the content of iron in lathe waste was 97 $\%$ [9].

Iron oxide pigments reduce the swelling of the wood. According to Lu., B [10], the hematite's surface is very reactive to water. The hematite surface can interact with water during dialysis, as evidenced by the FT-IR results, which show the number of $\mathrm{OH}$ groups. Composite hematite can reduce the surface area of the composite, thereby reducing its adsorption. Based on Ariyani [11], the composition $1: 1$ of iron-carbon oxide composite has a surface area of $219.59 \mathrm{~m}^{2} / \mathrm{g}$ while $0: 1$ a surface area of $1057 \mathrm{~m}^{2} / \mathrm{g}$. Iron oxide composites: carbon has a smaller surface area than the surface area of carbon without being composited with iron oxide.

In view of hematite as a pigment, the present investigations were undertaken to synthesis hematite by the precipitation-calcination method. The precursors were prepared from lathe waste and followed the effect 
of temperature. Hematite has been synthesized is applied to wood, and analyzed swelling on wood.

\section{EXPERIMENTAL}

\subsection{Material}

The materials used in this study were iron lathe waste, wood powder, methanol p.a, $\mathrm{HNO}_{3} 65 \%, \mathrm{NaHCO}_{3}$ p.a, $\mathrm{H}_{2} \mathrm{SO}_{4}$ p.a, were purchased from Merck.

\subsection{Method}

\subsection{1 making a precursor}

A total of 10 grams of iron lathe waste was put in a $500 \mathrm{~mL}$ glass beaker and added with $100 \mathrm{~mL}$ of $5 \mathrm{M}$ $\mathrm{HNO}_{3}$. The solution allowed standing for 24 hours so that it dissolved completely then heated on a hot plate.

\subsubsection{Synthesis Hematite Pigment}

The precipitate is dissolved in $250 \mathrm{~mL}$ of distilled water. The mixture is stirred till it forms a slurry yellowish-brown mixture, then added $25 \mathrm{~mL}$ of $0.5 \mathrm{M}$ $\mathrm{NaHCO}_{3}$ and adjusted to $\mathrm{pH}$ 6. The mixture was then heated on a hotplate at $70^{\circ} \mathrm{C}$ and distilled for 1 hour, then cooled to room temperature. The mixture was decanted, then filtered with Whatman 41 paper and washed with $300 \mathrm{~mL}$ of distilled water. The precipitate is dried until it turns into powder. The powder is heated in a furnace at $750^{\circ} \mathrm{C}$ and $850^{\circ} \mathrm{C}$ for 3 hours and then cooled in a desiccator to obtain a red powder [9]. The product was analyzed by XRD, SEM, color reader, and FT-IR.

\subsubsection{Pigmented wood with hematite iron oxide}

The resulting pigment is then dissolved with methanol at a ratio of 1: 10, stirring so that it is completely dissolved. Furthermore, the prepared wood powder interacted with the dissolved hematite pigment using a shaker for 20 minutes. The wood powder pigmented with hematite was filtered and oven at $30^{\circ} \mathrm{C}$ until constant weight, then analyzed by FT-IR. The same way is done using sulfuric acid, then tested its swelling ability at time intervals of $3,8,24,48$, and 72 hours.

\section{RESULT AND DISCUSSIONS}

\subsection{Characterization with $\mathrm{XRF}$}

Based on the XRF results in Table 1, many elements found, but the number was small, except iron was 96.08 $\%$. It was indicated that iron is the potential to be a precursor in synthesizing hematite.

\subsection{Characterization with X-ray Diffraction}

The X-ray diffraction (XRD) pattern of hematite is illustrated in Fig. 1. The figure shows that pure hematite achieved using the precipitation-calcination method at $750^{\circ} \mathrm{C}$ and $850^{\circ} \mathrm{C}$.

Table 1. XRF data for raw material of lathe waste

\begin{tabular}{|c|c|}
\hline Element & \% Amount \\
\hline Iron $(\mathrm{Fe})$ & 96.08 \\
\hline Mangan $(\mathrm{Mn})$ & 1.3 \\
\hline Europium $(\mathrm{Eu})$ & 0.9 \\
\hline Nickel $(\mathrm{Ni})$ & 0.82 \\
\hline Rubidium $(\mathrm{Rb})$ & 0.66 \\
\hline Calcium $(\mathrm{Ca})$ & 0.29 \\
\hline Chromium $(\mathrm{Cr})$ & 0.096 \\
\hline Cuprum $(\mathrm{Cu})$ & 0.093 \\
\hline Lanthanum $(\mathrm{La})$ & 0.02 \\
\hline
\end{tabular}




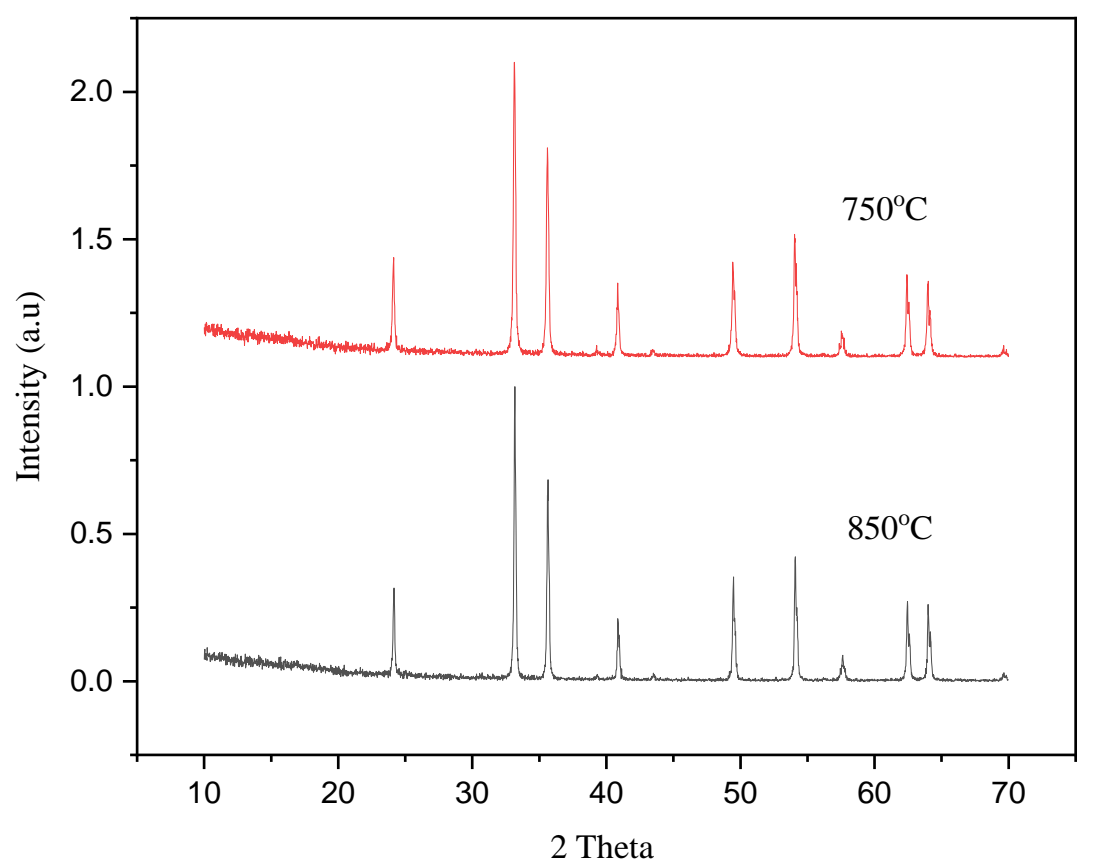

Figure 1. Diffraction pattern of hematite

All of the peaks are indexed to rhombohedral $\alpha-\mathrm{Fe}_{2} \mathrm{O}_{3}$ with space group R-3c and parameter $\mathrm{a}=5.0356 \mathrm{c}=$ 13.74. The peak can be attributed to the (012), (104), (110), (113), (024), (116), (018), (214), and (300) crystalline structures corresponding to pure $\alpha-\mathrm{Fe}_{2} \mathrm{O}_{3}$ (matched with PDF No- 00-33-0664). No extra peaks for impurities were detected, indicating high purity and crystallinity in both diffractions. The higher crystallinity of hematite was achieved at $750^{\circ} \mathrm{C}$, as shown by the higher intensity. The average crystallite size of hematite synthesized was calculated using Debye-Schrerrer's equation. The average crystal size at $750^{\circ} \mathrm{C}$ was $0.15 \mathrm{~mm}$, and $850^{\circ} \mathrm{C}$ was $0.16 \mathrm{~mm}$. Both of temperatures were not significantly different, showing the temperature didn't affect the crystal size. Temperature changes that are not much different produce crystal size not different too.

\subsection{Characterization with Color Reader}

Based on the results of the color reader measurements in Table 2, the synthesized compounds after precipitation was by akagenite standard except for hue value and after calcination was following the standard. At $750^{\circ} \mathrm{C}$, the degree of yellowness, redness, hue, and saturation was higher than $850^{\circ} \mathrm{C}$; this is due to the larger grain size at that temperature.

\subsection{Characterization with SEM}

The morphology of hematite at $850^{\circ} \mathrm{C}$ revealed particle shape distribution is relatively spherical and uniform. The particle size of hematite at $750^{\circ} \mathrm{C}$ is around $0.09 \mathrm{~mm}$, as seen in Figure 2. The shape, size, and distribution of particles are the factors that influence the resulting color. Particle size and distribution of particles cause different color values in the optical analysis. The degree of redness, yellow, hue, and chroma hematite $750^{\circ} \mathrm{C}$ is greater than the synthesized hematite at a temperature of $85^{\circ} \mathrm{C}$.

Table 2. Optical data of product syntesized

\begin{tabular}{c|l|l|l|l|l|l}
\hline \multirow{2}{*}{ Condition } & \multirow{2}{*}{$\begin{array}{c}\text { Temperature of } \\
\text { synthesis }\end{array}$} & \multicolumn{5}{|c}{ Color } \\
\cline { 3 - 7 } & & $\mathrm{L}^{*}$ & $\mathrm{C}^{*}$ & $\mathrm{H}^{\circ}$ & $\mathrm{a}^{*}$ & $\mathrm{~b}^{*}$ \\
\hline After Precipitation & $70^{\circ} \mathrm{C}$ & 37,2 & 23,5 & 17,6 & 29,36 & 36,8 \\
\hline \multirow{2}{*}{ After Calcination } & $750^{\circ} \mathrm{C}$ & 33,5 & 20,4 & 35,0 & 16,7 & 12,3 \\
& $850^{\circ} \mathrm{C}$ & 32,5 & 19,2 & 30,7 & 16,5 & 9,8 \\
\hline
\end{tabular}



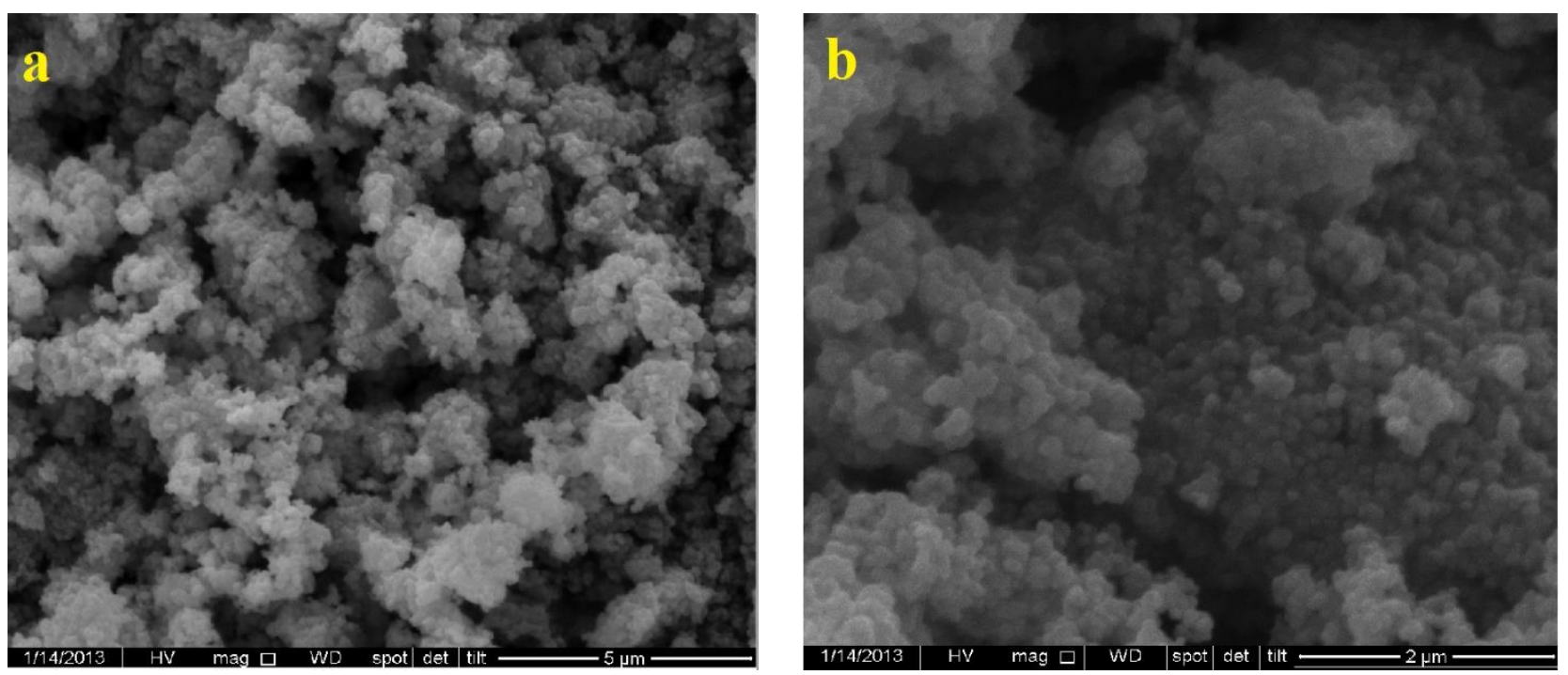

Figure 2. SEM image of hematite at $850^{\circ} \mathrm{C}$ : (a) low magnification and (b) higher magnification

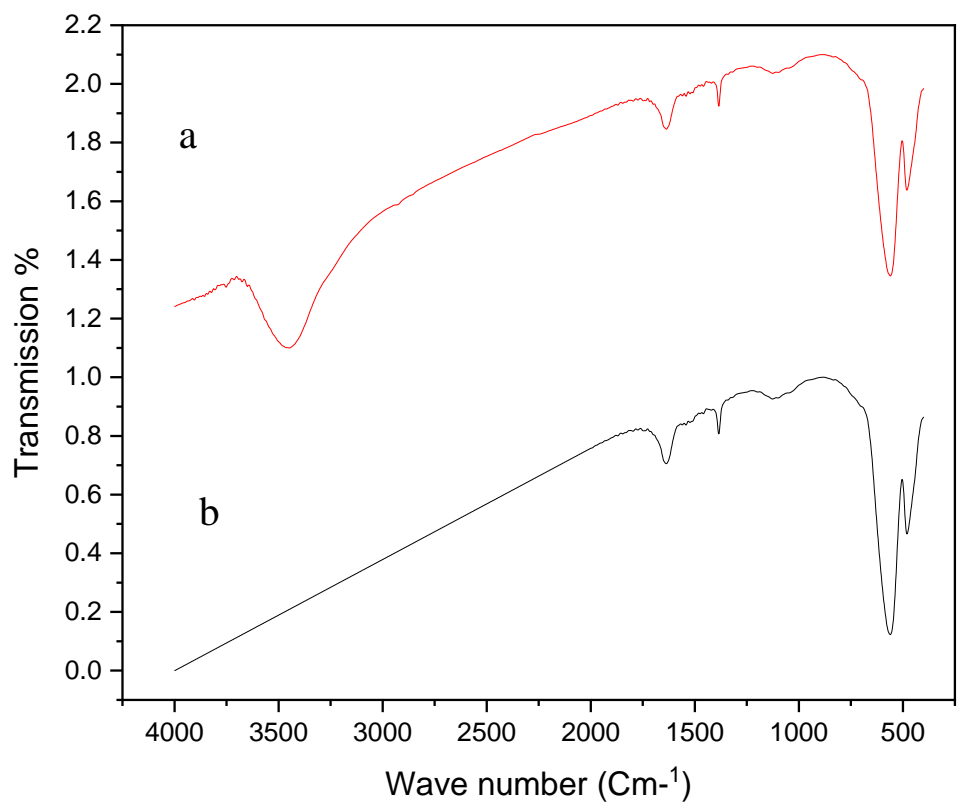

Figure 3. FT-IR spectrum of product synthesized; (a) after precipitation (b) after calcination

\subsection{Characterization with FT-IR}

Figure 3 shows the FTIR spectra of iron oxide. All of the vibration after precipitation same with calcination except at $3448 \mathrm{~cm}^{-1}$, indicating $\mathrm{OH}$ vibration. There is $\mathrm{OH}$-bending vibration at $1636 \mathrm{~cm}^{-1}$, there is $\tau-\mathrm{O}$ vibration in the bond plane at $1384 \mathrm{~cm}^{-1}$, and the t-O vibration at $560 \mathrm{~cm}^{-1}$, and the Fe-O stretching vibration at $499 \mathrm{~cm}^{-1}$. Based on these vibrations, the possibility of a product after precipitation is akagenite.
The characterization of swelling power was carried out to determine synthesized compounds' ability to reduce wood swelling. Wood is a material that contains high levels of cellulose, lignin, hemicellulose, and other contents. One solution to avoid the problem of fungus on wood is to coat it with pigments.

The wood interacted with the synthesized compound, dissolved in two different solvents, namely using $\mathrm{H}_{2} \mathrm{SO}_{4}$ and methanol. After interacting with the dissolved pigment, then dried and characterized by FT-IR, as shown in Figure 4. The spectra show that hematite pigmented wood with methanol solvent revealed $\mathrm{OH}$ 
vibrations at around $3427 \mathrm{~cm}^{-1}, \mathrm{C}=\mathrm{O}$ vibration at about $1623 \mathrm{~cm}^{-1}, \mathrm{C}=\mathrm{C}$ at around $1509 \mathrm{~cm}^{-1}$, and vibrations of Fe-O stretching at $485 \mathrm{~cm}^{-1}$. Spectra IR hematite pigmented wood with $\mathrm{H}_{2} \mathrm{SO}_{4}$ solvent is not much different from methanol solvent; just vibrations for $\mathrm{H}_{2} \mathrm{SO}_{4}$ solvent has higher intensity.

\subsection{Swelling Ratio of Wood Powder}

The wood powder interacted with the pigment is analyzed by swelling using water. Based on Figure 5, the wood powder interacting with hematite using $\mathrm{H}_{2} \mathrm{SO}_{4}$ solvent did not swell at all. If with methanol solvent, the swelling power of wood powder is $4.76 \%$ at 8 hours. The wood not interacted with the hematite has experienced swelling of $2.5 \%$ at 3 hours, and the swelling power increases with time.

The wood's swelling shows that the synthesized compound can coat wood powder to prevent swell on wood. Pigments can prevent hydrogen bonding with cellulose in wood, thereby minimizing hydrogen bonds, causing swelling

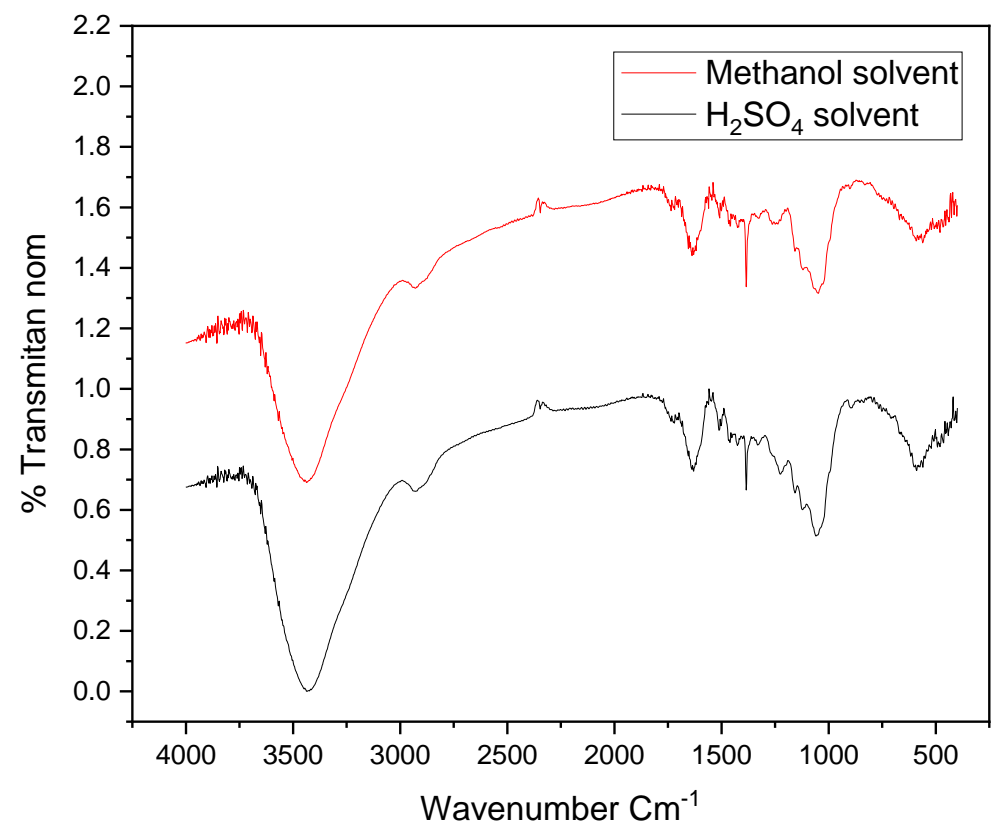

Figure 4. FT-IR spectra of hematite pigmented wood

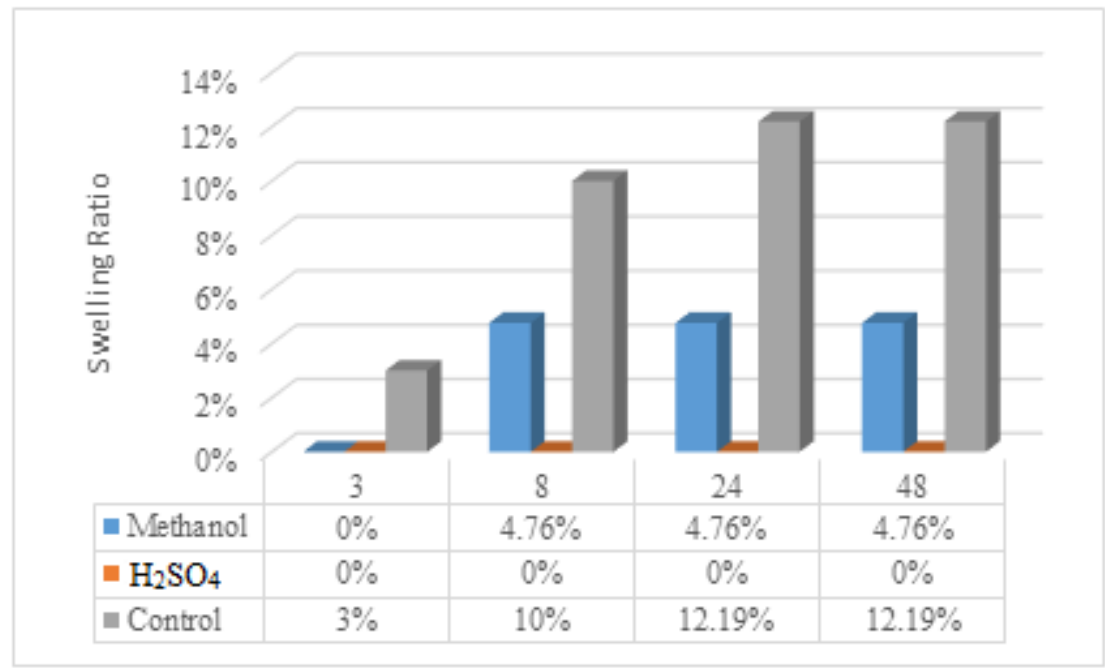

Figure 5. Graph of the swelling ratio of hematite pigmented wood powder 


\section{CONCLUSION}

Hematite with a high degree of crystallinity can be synthesized from lathe waste at $750^{\circ} \mathrm{C}$. Hematite pigment can coat the wood to prevent swell. Hematite pigmented wood using $\mathrm{H}_{2} \mathrm{SO}_{4}$ solvent didn't experience swelling at all.

\section{ACKNOWLEDGMENTS}

Some of this research are funded by Science and Technology Faculty UIN Maulana Malik Ibrahim Malang.

\section{REFERENCES}

[1] C. A. Eckelman, "The Shrinking and Swelling of Wood and Its Effect on Furniture," p. 26.

[2] A. M. Eriksen, D. J. Gregory, and H. Matthiesen, "The importance of cellulose content and wood density for attack of waterlogged archaeological wood by the shipworm, Teredo navalis," J. Cult. Herit., vol. 28, pp. 75-81, Nov. 2017, doi: 10.1016/j.culher.2017.06.005.

[3] C. Laine, "STRUCTURES OF HEMICELLULOSES AND PECTINS IN WOOD AND PULP," p. 64.

[4] R. Mohadi, N. Hidayati, A. Saputra, and A. Lesbani, "KAJIAN INTERAKSI ION $\mathrm{Co} 2+$ DENGAN SELULOSA DARI SERBUK GERGAJI KAYU," J. Appl. Chem., vol. 1, p. 8, 2013.
[5] J. A. Howsinon, "Book Reviews: Physics and Chemistry of Cellulose Fibres (with Particular Reference to Rayon). P. H. Hermans. New York, Elsevier Publishing Com pany, 1949. 534 pages. Price, \$9.50," Text. Res. J., vol. 19, no. 12, pp. 835835, Dec. 1949, doi: 10.1177/004051754901901212.

[6] V. Repellin and R. Guyonnet, "Evaluation of heat treated wood swelling by differential scanning calorimetry in relation with chemical composition," p. 26.

[7] A. Schirp, B. Plinke, and D. Napolow, "Effectiveness of organic and inorganic pigments for mass colouration of thermo-mechanical pulp used in wood-plastic composites," Eur. J. Wood Wood Prod., vol. 73, no. 1, pp. 5-16, Jan. 2015, doi: 10.1007/s00107-014-0839-z.

[8] R. M. Cornell and U. Schwertmann, The iron oxides: structure, properties, reactions, occurrences, and uses, 2nd, completely rev. and extended ed ed. Weinheim: Wiley-VCH, 2003.

[9] L. M. Khoiroh, M. N. Al-Chabib, and A. Prasetyo, "Synthesis and characterization of hematite $\left(\alpha-\mathrm{Fe}{ }_{2}\right.$ $\mathrm{O}_{3}$ ) from lathe waste using co-precipitation calcination method," IOP Conf. Ser. Mater. Sci. Eng., vol. 578, p. 012004, Oct. 2019, doi: 10.1088/1757-899X/578/1/012004.

[10] B. Lu, "Surface Reactivity of Hematite Nanoparticles," p. 38.

[11] Ariyani, 2011, Pembuatan Komposit Magnet Oksida Besikarbon Aktif Sebagai Adsorben Cs Dan Sr, Sripsi, Institut Pertanian Bogor. 